\title{
Джани-Заде T.М.
}

\section{Рефлексия понятия макам в культуре исламской цивилизации: генезис музыкального феномена}

\begin{abstract}
Аннотация: Объектом исследования в статье выступает категория макам, неодно-
\end{abstract} значно понимаемая сегодня при описании «классических» музыкальных традиций мусульманского Востока. С целью выявления генезиса понятия привлекаются исторические данные о систематизации ладов в средневековой культуре исламской цивилизации (VII-XVII века). Представлена концепция о трех этапах развития музыки в исламской цивилизации, определяемых рождением литературных языков (арабского, персидского, туреикого) с доминированием иранских элементов культуры в XI-XIV веках. Раскрываются особенности творчества Барбада, Ибрахима ал-Маусили, Сафи ад-Дина, Кутб ад-Дина и других, причастных к формированию представлений о ладах. Анализ музыкальных терминов, рефлектирующих средневековые лады, их наименования, номенклатуру, позволяет утверждать: термин макам стал употребляться не в арабских, а в персидских и турецких трактатах после XIV века наряду с аналогичными лексемами (шадд, ангам, парде, даур), предназначенными для определения интервальной структуры лада - звукоряда. Однако, категория макам/ макамат не является аналогом «лада»/«народных ладов», а выражает новую иивилизационную сущность, раскрытию которой способствовала разработанная в XIII веке Саби адДином система ладов (12 шудуд и 6 авазат). В ее основе лежала идея та'сир («этос») - эмоционального воздействия двенадцати ладов (а не отдельных тонов) на человека и характер народов. Антропопатическая направленность данного учения сближала музыку с астрологией и терапией, служила развитию концепции музыкального искусства, которое с помощью широко распространенного термина макам («стоянка», «станция»), вводимого в суфийские, терапевтические, музыкальные трактаты, наполнялось эзотерическим опытом. Макам стал для музыкантов не столько узко теоретической категорией для обозначения лада, сколько центральным понятием для определения места музыки в культуре мусульман. Исторический и культурологический методы являются основными в данной статье. Они позволяют выделить особенности исследуемой культуры и достичь адекватности в постижении ее музыкального искусства при анализе исторических данных по музыке и теоретической интерпретации аутентичных музыкальных категорий, относящихся к формированию представлений о ладах в целом, и о макаме в частности. Макам впервые очерчен исторически, как объект музыковедческого исследования, выявлено не древнее, а достаточно позднее появление данной категории в музыкальных трактатах, конкретизировано его музыкально-теоретическое описание в рукописях до 15 века. Результаты исследования генезиса музыкальной категории макам предоставляют возможность исторически более адекватного ее понимания и способствуют проведению дальнейших исследований, как в области изучения современных региональных (национальных) музыкальных традиций, связанных с феноменом макам, так и в исследованиях сравнительного характера.

Ключевъе слова: Макам, ладовая система, Исламская цивилизация, арабская, иранская, трактаты, Средний Восток, Исследовательская группа макам, средневековая, цивилизационная стадия музыки.

Review: The object of this research is the category of Maqam, which is ambiguously understood in the process of the description of "classical" music traditions of the Muslim East nowadays. To identify the genesis of this category the researcher has involved historical data about mode systematization in the medieval culture of the Islamic civilization (VII-XVII century). The researcher has also introduced the concept of the three stages in the development of music in the Islamic civilization, defined by the birth of the literary languages (Arabic, Persian, Turkish) with the domination of Iranian culture in the XI-XIVth centuries. Features of musical creativity of Barbad, Ibrahim al-Mawsili, Safi ad-Din, Qutb ad-Din and others are considered; these musicians took part in the formation of the modes. The analysis of musical terms, which describe the medieval modes, their names, nomenclature, helps to understand the following: the term Maqam began to be used not in Arabic, but in Persian and Turkish treatises after the XIVth century, along with similar terms (shadd, an- 
gam, parde, dawr) designed for determining interval patterns - scales. However, the category of Maqam/Maqamat is not analogous to the category of "mode"/"folk modes", it expresses the essence of a new civilization, the disclosure of which contributed to the system of modes (12 shudud and 6 avazat) developed in the XIII century by Safi al-Din. This system was based on the idea of "ta'sir" ("ethos") - emotional impact of twelve modes (not single tones) on the person and the character of the nations. Anthropopathetically the character of this teaching connects music with astrology and therapy, and develops the concept of musical art that was enriched with esoteric experience with the help of the widespread term 'Maqam' (meaning 'place' or 'station'), which was introduced into the Sufi teaching, therapeutic and musical treatises. For musicians the Maqam concept has become rather the basic concept for determining the place of music in the culture of Muslims than the theoretical category to signify a mode. The main research methods used include historical and cultural analysis. These methods allow to define peculiarities of the Muslim culture as well as to develop an adequate understanding of Muslim musical art when analyzing historical data and facts about music and theoretical interpretation of authentic musical categories which refer to the development of the ideas about modes in general and Maqam in particuylar. For the first time in the academic literature Maqam is studied from the historical point of view and as a an object of musicological research. The researcher also describes the later genesis of that category in musical treatises and analyzes its theoretical concept in the writings created before the XVth century. These findings provide an opportunity to study the contemporary regional (national) musical events associated with the phenomenon of Maqam and to make the comparative studies in a more adequate way.

Keywords: Arabic, Islamic civilization, Iranian, treatises, Middle East, maqam, Study Group maqam, mode system, civilization stage of music, medieval.

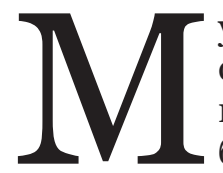

узыкальные явления, связанные с понятием макам, вызвали во второй половине XX века особый интерес со стороны ученых. Сегодня представления по данной теме у большей части музыковедов нашей страны опираются на концепцию, формировавшуюся еще в советские годы, когда изучение таких явлений в музыке Востока, как мугам, маком, мукам, дастаах, осуществлялось по принципу выделения тех же структур и образов, что уже были известны в музыкальном фольклоре или творчестве композиторов. В конце 70-х - начале 80-х годов прошлого века отношение к названным явлениям изменилось. Они стали рассматриваться в качестве самостоятельного «устно-профессионального» пласта музыки, выделяющегося, прежде всего, в культуре Среднего Востока (В.Дж. Конен, Н.Г. Шахназарова). В этом вопросе по существу новой стала культурологическая концепция М.Г. Харлапа о «трех исторических стадиях» в развитии музыки [1, с.500-501]. Его работы и выступления помогли «распознать» специфику третьей стадии, которая отличалась от фольклорной и композиторской. Харлап определял ее терминами «мусическая», «мензуральная», «музыкально-литературная». В моих работах данная стадия получает определение «цивилизационная».
Интенсивное изучение аутентичных образцов музыкального репертуара, связанного с термином макам (араб. - «место пребывания», «стоянка»; мн.ч. - макамат), началось в те же годы и потребовало не только представлений о трех стадиях музыки, но и новых аналитических средств, не совпадающих полностью с теми, что были разработаны в фольклористике и в исследованиях по зарубежной и русской музыке. Заметную роль играла тогда идея «импровизации». Под влиянием лингвистики и семиотики в моих работах традиционная парадигма «импровизация не есть композиция» получала иной ракурс, поскольку в результате сравнения нескольких образцов «восточной импровизации» с характерным для нее «программным» заголовком в виде лада («Раст», «Шур», «Нава», «Сегах» и пр.), обнаруживалась единая структурная модель, определяемая мною как канон («художественный» и «технологический»). Поиск адекватного описания данной модели, правил конструирования «импровизации на лад», составлял основную проблему моих исследований в те годы [2-5]. И она оказалась во многом аналогичной поискам «принципов макама» некоторых зарубежных ученых, в частности, Ю. Эльснера [6]. Сегодня, приходится признать, что идея канона и импровизации не дала возможности раскрыть во всей полноте феномен макама. Видимо, потому, что опи- 
ралась в основном на синхронический ракурс исследования, рассматривая образцы современной музыкальной практики в условиях национальной культуры. Отсутствовал диахронический ракурс, который необходим для достижения адекватности при погружении в «чужую» культуру и который составляет основу культурологических методов исследования «исторической поэтики» А.Н. Веселовского.

К сожалению, большинство работ российских, азербайджанских, среднеазиатских музыковедов демонстрирует в наши дни поверхностное усвоение культурологических и исторических методов исследования. Многие авторы, не зная результатов зарубежных и отечественных работ, опираются либо на мифологизированные представления о «древнем» происхождении макама, либо на европоцентристские концепции, сравнивая плохо изученную «монодию Востока» с «монодией Запада». Цель настоящей статьи указать на основные моменты в осмыслении категории макам, имевшие место в истории ее возникновения, и дать представления о новом векторе и результатах, проводимых мною и зарубежными коллегами исследований по данной теме.

Макам - широко употребляемый сегодня термин, с которым связана суть музыкальной учености «классических» традиций мусульманского Востока. Для этномузыкологов с Запада и с Востока макам выступает в известном смысле «идеальным» объектом, отсылающим, безусловно, к культуре ислама. И это неслучайно, поскольку зарождение и существование данной категории относится к средним векам, к тому историческому периоду, когда в результате завоеваний аравийскими арабами обширной территории Среднего Востока на ней возникла культурная гиперсистема, определяемая мною как «Исламская цивилизация», существовавшая с VII по XVII века $[7,8]$. Не современное, но исторически далекое происхождение категории макам, ее неоднородное усвоение разными народами и регионами привело к тому, что она приобретает в наши дни слишком неопределенный смысл. Понять этот внеевропейский феномен, ставший вершиной цивилизационного развития музыки Среднего Востока и лежащий в основе современных национальных культур, действительно, непросто. Раскрытие сущности макама возможно лишь в случае, если рассматривать данную категорию с позиций исторической музыкальной теории и практики в контексте культуры создавшей его цивилизации.

Для обозначения общих черт в музыкальной «классике» мусульманского Востока в моих работах 1970-1980-х годов, посвященных в основном изучению азербайджанского мугама, употреблялся термин «искусство макамат» $[9,10]$. Такой широкий ракурс исследования, исходивший из признания очевидного сходства современного музыкального репертуара у разных мусульманских народов, начал проявлять себя в ряде исследований тех лет. На лицо было стремление исследователей сравнивать музыкальный материал разных стран Среднего Востока. «Интернациональной» научной парадигме способствовало расширение контактов между учеными бывшего Советского союза и зарубежными коллегами, которые приняли участие в музыковедческом симпозиуме Международного совета по традиционной музыке (International Council for Traditional Music). Он проводился в СССР три раза в городе Самарканде (1978, 1983, 1987 годы). Событие это оказалось актуальным для музыкальной науки, вызвав большой интерес к музыкальным традициям, связанным с феноменом макама. Поэтому главным итогом самаркандских встреч стало создание в рамках ICTM Исследовательской группы по изучению макама (Study Group on maqām). Инициаторами ее создания были Ю. Эльснер (ГДР), Г. Пауэрс (США), Ф.М. Кароматов (CССР). Работа этой группы началась в 1989 году, а последнее заседание проводилось совместно с участниками Исследовательской группы по музыке арабского мира в декабре 2014 года в Анкаре. Цель исследований, проводимых участниками группы «макам», была заявлена в статье Эльснера и Кароматова, как глубокое изучение региональных музыкальных практик и теорий, а также всех исторических материалов [11, с.135]. По итогам семи международных сессий были изданы сборники статей, научная ценность которых очевидна [12-18], поскольку участниками группы были ведущие исследователи: арабской музыки - Ю. Эльснер и Х. Тума (Германия), Ш. Хассан (Франция), Р. Девис (Англия); иранской - Ж. Дюринг (Франция) и М.Т. Массоуди (Иран), кашмирской - Й. Пахульчик (США), индийской - Г. Пауэрс (США), турецкой Ф. Тансуг, Я. Тура (Турция) и В. Фельдман, К. Сигнель (США); известные переводчики средневековых рукописей - О. Райт (Англия), А. Шилоа (Израиль). Активными участника- 
ми стали также представители Средней Азии и Азербайджана: Ф. Кароматов, А. Джумаев, А. Хашимов, О. Матякубов, А. Мухамбетова, С. Агаева, С. Багирова и др. Принимая участие во многих встречах группы макам, я получила редкую возможность познакомиться с видными учеными, с методами и результатами их работ, лучше понять те проблемы, которые возникают сегодня при изучении внеевропейской музыки в целом и феномена макам, в частности.

Наряду с широким диапазоном новых данных о музыке разных регионов исламского мира, полученных в ходе работы группы, одной из главных проблем остается проблема генезиса понятия макам в музыке. Вместе с тем, решение именно данной проблемы позволяет лучше очертить и понять объект исследования [19], адекватно постичь который возможно, по моим представлениям, только при установлении отличий культуры исламской цивилизации, в которой он возник и развивался, от современных культур Среднего Востока. Наиболее значимыми в данном вопросе оказываются, пожалуй, два признака той культуры, где формировались представления о макаме:

Первый, - рождение исламской цивилизации и нового музыкального профессионализма осуществлялось в гетерогенной среде, но, прежде всего, в центральном ирако-иранском регионе на основе симбиоза арабских элементов культуры с иранскими. В исламской музыке проявились не только элементы трех больших этносов (арабского, иранского и тюркского), но и пласты древних цивилизаций (эллинистической, сирийско-византийской, древнегреческой, древнеиранской). Определяющим фактором цивилизационной стадии культуры является теснейшая связь музыки с литературным, письменным творчеством арабов. Причем, способ взаимодействия музыки с поэзией на данной исторической стадии принципиально отличался от стадии фольклорной. Основополагающим было творчество авторское - создание музыкального «текста» профессиональным музыкантом, «певцом-сочинителем» (муганни, мутриб, хонигар) по особым правилам (шарт-е мутриби). При этом певец мог быть одновременно и автором стихов (поэтом - wa'up), а часть певцов, будучи ученикамиподмастерьями, поначалу овладевала чужими сочинениями, которые создавали мастера, чьи имена запечатлены в исторических и литературных памятниках.
Новый тип музыкального ремесла был вполне светским и получил в VIII веке определение «искусства» на арабском языке - языке, объединившем всех мусульман, подобно латинскому языку в Европе: ас-сана'а л-гuна' (букв. - «искусство пения» в греческом понимании, как «техне», «ремесло»). Распространенный термин ал-гина' отличался от термина «музыка» (араб. - ал-мусики) - слова греческого, и потому - «чужого». Термин алмусики вошел в употребление после IX века, и не был столь широко распространен, как термины «родные» арабские - ал-гина' и алхан. Он в основном употреблялся в трактатах, которые положили начало письменной традиции «музыкальной науки», «учения о музыке» ('илм ал-мусикu) [20, с102-103]. Эта традиция будет интенсивно развиваться с IX века наряду с другими «науками», точнее - «знаниями» ('илм ал-хадис - «знание преданий о Пророке», 'улум аш-шu'up - «науки о поэзии» и т.п.). Музыкальная теория следовала во многом за музыкальной практикой, которая обретала черты профессионализма. Сочинение «песни» (араб. - caym, перс. - аханг) опиралось на создание мелодии с новыми «метрами» (uка'am, ед.ч. - ика'). При этом музыкант подбирал поэтический текст на литературном арабском языке к уже созданной «размеренной мелодии» (лахн) с условием: соблюдать правильное расчленение (кисма) арабского стиха, «укладывая» его метрику в готовые (образцовые) музыкально-ритмические формулы (алхан). Эти метрические формулы были искусственно выведены из арабской просодии в начальный период цивилизации. Причем, осуществлялось это практически одновременно придворным музыкантом Ибрахимом ал-Маусили (ум. 804) в Багдаде, который эмпирически выделил основные метро-ритмические модели, опираясь на собственное размеренное пение арабского стиха, и филологом 'Абд ар-Рахманом Халилем ибн Ахмадом (ум. 791) в Басре, который получил сходные модели в процессе теоретического описания арабской поэтической метрики, создав учение о классическом стихосложении - 'apyд|'apyз. Знание этой новой музыкально-поэтической системы определяло, прежде всего, профессионализм музыкантов в IX-X веках. О расцвете такого типа авторского творчества музыкантов и поэтов при халифах династии 'Аббасидов повествует главный документ X века «Большая книга песен» (Китаб ал-агани ал-кабир) Абу'-л-Фараджа ал-Исфахани (ум.967). 
Второй момент, - по своей сути исламская цивилизация имела надэтнический характер. Она была инициирована арабской культурой, но в процессе своего развития пережила три этапа, вызванных последовательным рождением трех великих литератур: арабской, персидской и турецкой. Тесная связь музыки с литературой определила появление новых рубежей в музыкальном искусстве, обнаруживая в истории музыки последовательную смену трех различных «культурных доминант» - арабской, иранской и тюркской [7]: 1) на этапе формирования исламских ценностей (VII-X вв.), определяемом арабским языком и письменностью, рождается «музыкальное искусство» и «музыкальная наука», осваиваются знания о музыке древних греков и оформляются представления о звуковой системе (ангам), о музыкальной ритмике (uка'am); 2) на этапе расцвета исламских форм музыки (XI- XV вв.), совпадающим с рождением ново-персидского языка и персидской литературы, с расцветом мистического «учения суфиев» ('илм am-тасавву $\phi)$, получает распространение особый стиль пения персидской газели - в декламационной манере без метра и с опорой на лад; появляется учение о ладах-макамат, развивается персидская музыкально-трактатная школа и музыкально-терапевтическая наука; 3) в период консервации исламских ценностей (XV-XVII вв.) появляется турецкая (тюркоязычная) литература; на фоне угасания придворных певческих традиций и музыкальной теории интенсивно развиваются инструментальные формы, распространяются новые музыкальные инструменты и региональные виды ладов, ритмов, жанров [21].

Естественно встает вопрос: употреблялся ли термин макам на раннем этапе формирования исламской музыки? - Ответ однозначный: нет! Такого понятия не существовало ни в музыкальной практике, ни в музыкальной теории. Исторические документы упорно свидетельствуют об этом. Благодаря работам ведущих западноевропейских ученых (Г.Дж. Фармера, Э. Нойбауэра, О. Райта, А. Шилоа), мы имеем возможность составить представление, когда и как термин макам начал употребляться в музыкальной науке. Точность перевода средневековых рукописей здесь чрезвычайно важна, особенно в отношении музыкальных терминов, которые, взаимодействуя друг с другом, образуют определенный терминологический комплекс представлений о ладах. В связи с этим основополагающим явля- ется вывод Фармера о существовании трех теоретических «школ» в исламской музыкальной науке: «староарабская» - школа ранних музыкантов-практиков VII-IX века, представленная придворными музыкантами Дамаска и Багдада (Ибрахим и Исхак ал-Маусили, их окружение); школа «греческих схоластов» IX-XI веков (Ал-Кинди, Ал-Фараби, Ибн Сина, Ибн Зайла); школа «исламских систематиков» XIII-XVI веков (Сафи ад-Дин, Кутб ад-Дин, Ал-Мараги, Ал-Ладики, Джами и др.) [22]. Обращение к трактатам показывает, что термин макам не употреблялся ни багдадскими музыкантами на первом этапе цивилизации, ни прославленным 'Абу Насром ал-Фараби (ум. 950) и его последователем Ибн Синой (ум.1037) на втором этапе ее развития. Ибн Сина, правда, упоминал в трактате Китаб аш-шифа' («Книга исцеления») названия нескольких ладов (мустаким=Pacm, Исфахан, Салмак), которые бытовали в его время в творчестве иранских музыкантов. Однако, Ал-Фараби, создавший учение о «совершенной музыкальной ритмике» и внесший вклад в изучение звуковой системы и музыкальных инструментов, не описывал систему ладов в своих работах.

Обратимся к главным источникам, позволяющим обнаружить представления о макаме в музыке. Последние возникали в результате рефлексии ладовых структур. При этом значительный вклад в разработку понятий, связанных с областью лада, внесли иранские музыканты. Так, большая часть базисных музыкально-теоретических понятий (тоннагме, модус-алхан, метр-ика', композицията'алиф), которые войдут позже во все трактаты, использовал уже в VIII веке Ибрахим ал-Маусили - выходец из Фарса, вольноотпущенный раб при дворе халифов в Багдаде. Однако, термина макам в учении этого знаменитого певца не было. В его время музыканты уделяли первостепенное внимание не ладам, а метро-ритмам, классифицируя мелодии по наименованиям восьми метровuка'am, которые выделяли Ибрахим и его сын Исхак ал-Маусили (ум. 850) [23, с.104]. Вместе с тем, рефлексия ладо-интанационных комплексов у этих музыкантов тоже получила развитие в виде обозначений: «сочинение ладов»/«сочинение мелодий» (тал'лиф аллухун/ тал'лиф ал-алхан). Известно, что, основываясь на близкой по составу интервалов к пифагореской 10-тоновой «звуковой системе» (ангам), согласно сведениям Йахйи ибн 
‘Али ал-Мунаджджима (ум.913), Ибрахим алМаусили опирался на восемь октавных ладов. Они назывались «пальцевыми», так как выделяли мелодические отрезки, возникающие в игре на «лютне» (араб. - ал-' $y$ ) при гаммообразном движении пальцев по мелодической струне (матна). Определяясь практикой исполнения на инструменте, лады получали свои наименования со словами: «ход» (араб. маджра) и «палец» (араб. лит. - асаби): «ход через средний палец» (би-маджра л-вуста) или “ход через безымянный палец” (бимаджра л-бинсир) и т.п. Лады эти стали подразделяться Исхаком ал-Маусили на две группы - по наличию в них либо большой терции (при участии в игре безымянного пальца), либо терции малой (с участием среднего пальца) [24, c.16-22].

Нельзя не заметить, что в этом раннем учении количество выделяемых музыкантами ритмических и ладовых структур было восемь. Такая номенклатура оказывалась тождественной сирийско-византийскому октоиху, представления о котором иранцы и арабы имели, поскольку тоже обозначали свои восемь ритмических модусов термином ал-лухун ассаманийа («восемь мелодических моделей») $[24$, c.5]. Однако, значение для музыкальнотеоретических представлений о ладе в это время имела не столько номенклатура, сколько стремление мастеров выразить важный момент в мелодическом ладообразовании это процессуальность. Ибрахим ал-Маусили, дкмаю, не случайно употреблял в названиях модусов хорошо известный древним иранцам термин «ход» (перс. - pax, в смысле: «ходом», «способом»). С помощью слова «ход» (араб. - маджра и тарика) музыкант осмыслял процесс ладообразования, подчеркивая зависимость лада не только от выбранных тонов (точнее, - интервалов), но и от мелодически определенной их последовательности.

Интересно, что через четыре века после Ибрахима и Исхака ал-Маусили то же слово «ход» (тарика) появилось в качестве некоей «музыкальной формы» у другого персидского музыканта Сафи ад-Дина 'Абд ал-Му'мина (ум. 1294 ). Он был родом из Урмии, расположенной на северных землях Ирана - в Азербайджане (среднеперс. «Адербайган» означает «Огненная земля»). У Сафи ад-Дина термин тарика использовался для обозначения инструментальной «прелюдии» в конкретном ладу, которая предшествовала распеванию поэтического текста в форме «песни» (caym) в том же ладу. По мнению О. Райта, который вслед за Фармером блестяще расшифровал образцы музыкальных записей, сделанные Сафи ад-Дином в трактате «Книга кругов» (Китаб ал-адвар,1236) с помощью буквенной нотации, термин тарика призван был обозначить определенную ладо-мелодическую формулу или «мелодический скелет» (Райт), который мог исполняться в нескольких разных ладовых звукорядах [25, с.245249]. По моим представлениям, употребление слова тарика Сафи ад-Дином наследовало более раннюю традицию описания ладов- $a c a-$ би Ибрахимом ал-Маусили в той же практике игры на yде, но по сути выражало уже смысл другого персидского термина - аваз (букв.«напев»), который Сафи ад-Дин ввел в том же трактате в качестве одного из генеральных в разработанную им систему ладов, наряду с другим генеральным термином - шадд (араб. - «настройка», «звукоряд»). Давая представление о тарике, как о музыкальной форме, Сафи Урмавийский тоже стремился подчеркнуть ее процессуально-динамические свойства, чтобы отличить от звукоряда-шадд. На эту мысль наводит тот факт, что в своих шести музыкальных примерах он не дает названия тех ладов, которые относятся к ладам-шудуд, а указывает либо названия выделенных им ладов-авазат («тарика Науруз», «тарика Кувешт»), либо название мелодии Мухаййар (у аш-Ширази - это шо'бе), основанной на части звукоряда Хусайни («Мухаййар Ху-

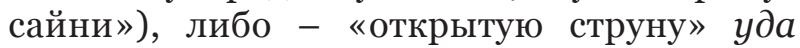
(мутлак), либо - «альтерированный» тон (муджаннаб). Такие подробные сведения о характере музыкального репертуара чрезвычайно ценны для понимания средневековой музыкальной практики, в которой имели место различные музыкальные формы, исполняемые как с метром, так и без него, но уже с указанием наименования конкретного ладо-мелодического комплекса.

Тот же принцип выделения типовых ладовых моделей с разными поэтичными названиями встречается у древних иранцев в классификации песнопений легендарным певцом Барбадом (585/589 - 638/639) [26, с.68]. Его имя часто упоминалось в первые века ислама музыкантами, которые обозначали ладо-мелодические комплексы Барбада \Фахлбада поарабски: си лахн (букв. «тридцать напевов») и ат-турук ал-мулукийа (букв. "царские ходы»; перс. - «рах-е Хусровани», букв. - «ходы Хусрова», или «соруд-и Хусровани» - «мело- 
дии Хусрова») [26; 27, с.191-196]. Последнее наименование подразумевало семь основных ладовых моделей. Свои песнопения Барбад исполнял под аккомпанемент лютни-барбат (предшественник $y \partial a$, получивший у арабов в VII веке наименование ал-'yд ал-фариси «персидский уд» [28, с.78]). Песнопения эти бытовали у иранцев под общими наименованиями «Хусрованийа», «Срот-и Хусрованик〉 Хосроваин», указывая на имя сасанидского шаха Хусрава Парвиза (590-628), при дворе которого в Ктесифоне служил музыкант. Очевидно, что Барбаду принадлежит первый (доисламский) опыт музыкальной систематизации в области ладо-интонационной, но не ритмической. Так как его песнопения, по известному утверждению филолога XIII века Мухаммада 'Ауфи, не подчинялись новому метру арабских стихов, и строй пехлевийской поэзии, тексты которой распевал Барбад, не опирался на метрику 'аруд, а потому, они считались «прозаическим». Вместе с тем связь исламской ладовой системы с доисламскими ладами Барбада будет прослеживаться в дальнейшем. Меняться будет принцип ее классификации. Ведь у Барбада система ладов опиралась на зороастрийский календарь, и все песнопения были приурочены к исполнению следующим образом: 360 мелодий (перс. нава) - на каждый день года, 30 мелодий (араб. лахн, перс. дастан ) - на каждый день месяца, 7 мелодий (араб. тарика, перс. соруд) - на каждый день недели [27, с.189; 29, с.46]. Последние семь песнопений имели особое значение и упоминались чаще других, так как их номенклатура обозначала связь музыки с семью планетами. С одной стороны, семь планет символизировали власть Хусрава, восседавшего на построенном для него «Сводчатом троне» с изображением небесной сферы [27, c.199], a, с другой стороны, эта была та же древнегреческая «планетарная» номенклатура, что легла в основу натурфилософской концепции музыки в исламе. Детальную разработку этой концепции можно найти у философа и придворного астролога в Багдаде, переводчика греческих трактатов на арабский язык и создателя первых книг по музыке 'Абу Йусуфа ал-Кинди (ум. после 870), а также - в известных «Посланиях Братьев чистоты» (Риса'ил Ихван ас-сафа, сер. Х в.). Систематика ладов Барбадом свидетельствует о наличии уникального музыкального опыта, который имели древние иранцы, их генетической (индоиранской) предрас- положенности к выделению интонационноладовых структур, но не структур ритмических, к систематизации которых оказались более предрасположены арабы.

Для исследования генезиса музыкального понятия макам огромное значение имеет факт первого появления наименований тех ладов, что будут определяться позже как макамат (и их части - шуббат). Показательно, что впервые наименования ладов-макамат мы находим не в музыкальных трактатах, а в художественной литературе XI-XII веков на персидском языке. Одним из ранних литературных источников, в которых упоминаются наименования Pacm, Ушшак, Науруз, Саркаш, является поэтический сборник (диван) персидского поэта Манучихри (ум. 1040) [30, c.236]. Очевидно, что до того, как те же самые наименования ладов попали в трактатную традицию, они бытовали с общим обозначением «лада» по-персидски - nарда|napде (букв. «занавес», «перемычка», «ладок», «тон»). Ценную информацию о ладах-парде, чьи наименования позже обретут небывалую известность, содержит персидский текст дидактического сочинения «Кабус наме» (Гурган/Джурджан,1083). Здесь перечислено восемь ладов: Раст, 'Ирак,'Ушшак, Зирафканд, Бусалик, Исфахан, Нава, Басте [31]. Семь из этих наименований появятся позже в трактате Сафи ад-Дина примерно через полтора века. О существовании развитой музыкальной практики, опирающейся на одни и те же лады-парде и даже на ту же самую номенклатуру октоиха говорит другое литературное сочинение - поэма «Хосров и Ширин» (Карабах, 1181) великого персоязычного поэта и мистика Низами Ганджеви (ум. 1203): Рacm, 'Ирак, Науруз, Исфахан, Хисар, 'Ушиак, Рахави, Зирафканд [32, с.284-303]. В поэме эти лады появляются в сцене обмена любовными посланиями между шахом Хусравом и армянской княжной Ширин («Хосров устраивает пир») во время поочередного исполнении газелей двумя музыкантами: Накисой, сопровождающим свое пение на арфе-чанг, и Барбадом с лютней-барбат. Больше половины перечисленных наименований совпадают с теми, что содержит текст «Кабус наме». И практически все эти имена из обоих литературных источников, исключая Науруз и Хисар, займут центральное место в трактате Сафи адДина. А бытующие до наших дней Науруз и Хисар будут упомянуты в качестве шоббат его ближайшим последователем персидским ав- 
тором Кутб ад-Дином аш-Ширази (ум. 1311) [25]. Таким образом, можно утверждать, что большинство знаменитых «двенадцати ладов», описанных в середине XIII века Сафи ад-Дином (Раст, 'Ирак, 'Ушшак, Нава, Зирафканд, Хусайни, Бузурк, Абусалик, Исфаган, Хиджази, Рахави, Зангуле), существовали намного раньше в музыкальной практике прикаспийского региона. Вместе с тем, Сафи ад-Дин не ограничился в своем учении только персидской музыкальной практикой. Он создал новую «исламскую» музыкальную систему, которая учитывала интервалы и лады, известные как иранцам, так и арабам, и тюркам. Например, он добавил еще четыре названия ладов, два из которых отличаются «цивилизационным» характером: Хиджази - область в Аравии, где возник ислам, Хусайни - имя третьего шиитского имама, младшего сына 'Али бин Аби Талиба от дочери пророка Мухаммеда Фатимы.

Созданное Сафи ад-Дином учение имеет большое историческое значение, определяя важный рубеж в развитии музыкального искусства. Об этом свидетельствует не только его обращение к ладам, но и их номенклатура. Совсем неслучайно музыкант выделил «двенадцать ладов», как наиболее распространенных из числа тех 84-х «звукорядов»-шудуд, что получались у него при вариантном соединении нетемперированных интервалов в пределах 17-ступенной звуковой шкалы. Все звукоряды-цудуд (в том числе и двенадцать выделенных) рассматривались теоретиком в диапазоне «октавы» (даур - букв. «круг»). Этот термин был положен в название его сочинения - «Книга кругов», где под «кругом» подразумевалась «периодичность» - либо метрическая, либо звуковысотная. Хотя Сафи ад-Дин писал свои трактаты по-арабски, он ввел в систему ладов термин персидский - аваз, выделив еще шесть ладов-авазат для обозначения отличающихся от звукорядовшудуд ладо-мелодических комплексов: Kyвашт, Карданийа, Науруз, Майа, Шахназ, Салмак. При описании авазат значимость в них имела уже не столько структура звукоряда (не все из них имели даже октавный диапазон), сколько вид мелодического движения, потому что автор указывал только на нисходящее следование тонов и на особые связи между отдельными тонами [22, с.40-42].

Обращает на себя внимание, что АлУрмави еще не использовал термин макам. Но, думаю, предпосылкой к появлению этого термина в последующих трактатах стала введенная музыкантом номенклатура - двенадцать. Ведь ею он указывал на новый способ связи музыки с космосом и с человеком посредством ладовых структур, давал возможность развивать представления о музыкальном искусстве в духе тех изменений, которые произошли в мусульманском обществе к XIII веку. Поэтому номенклатура «двенадцать» приобрела особое значение у всех «исламских систематиков». Выделенные родоначальником этой школы двенадцать ладовшудуд (в дальнейшем - двенадцать адвар или макамат) заняли центральное место для демонстрации связи музыки с явлениями экстрамузыкальными: с макрокосмом - в виде двенадцати знаков Зодиакального круга и двенадцати месяцев календарного годового круга, и с микрокосмом - в виде определенных эмоциональных состояний человека или темпераментов разных народов. Сафи ад-Дин не описывал подробно все связи музыкальных ладов с внемузыкальными факторами. Но остановился на эмоциональном воздействии лада в 14 главе своего трактата, которая называется «О влиянии тонов» $(\Phi u$ та'сир ан-нагам). Здесь им использован арабский термин та'сuр, который, как считает Фармер, употреблялся в отношении к музыке в том же значении, что и античный этос [33, с.311]. Ал-Урмави акцентирует воздействие музыкальных ладов на состояние души человека и подчеркивает необходимость соединять лады с «соответствующим родом поэзии». При этом он группирует двенадцать ладов по трем видам следующим образом: «Знай, что каждый лад (шадд) обладает воздействием (tâ'thīr=èthos) на душу, и что оно различного рода. Некоторые вызывают смелость, силу [в переводе О. Райта: «и радость»]; их три: Ушшак, Бусалик и Нава. И они соответствуют натурам тюрок, абиссинцев, эфиопов [у Райта: «негров»] и горцев. Что же касается Pacm, Науруз (это авазе), Ирак и Исфаган, то они умиротворяют душу приятным успокоением, восхищением [в переводе Райта: «утонченным весельем»]. Что касается Бузурк, Рахави, Зирафканд, Занкула, Хусайни и Хиджази, то они вызывают печаль и усталость» [33, с. 311-312; 25, с.82].

В результате созданной Сафи ад-Дином системы ладов число «двенадцать» обрело символический смысл, способствуя дальнейшему сближению музыки с астрологией и терапией. Э. Нойбауэр справедливо отмечает, что 
эта система отличалась от предшествующей древнегреческой тем, что в ней были выделены не отдельные тоны, а целые ладовые комплексы [30, с. 234]. Так Сафи ад-Дин дополнил натурфилософскую концепцию музыки, в которой выделялись отдельные элементы (тоны, струны, ритмы), ладами. Теперь посредством ладовых структур музыка устанавливала соответствие душевных качеств человека и народов с астрологическими атрибутами. Поэтому трактаты по терапевтической науке с XIV века стали использовать не только наименования двенадцати ладов Сафи ад-Дина, но и упоминать его имя, как и имя арабского поэта Ибн Хатиба ал-Ирбили (ум. 1354), описавшего те же двенадцать ладов (ангам), но с иным порядком их следования, начиная с Раст [30, с.237].

Определенно можно сказать, что с XV века термин макам будет применяться для обозначения не всех ладов-шудуд, а только двенадцати специально выделенных. При этом создается даже впечатление, что в последующем восприятии системы Сафи ад-Дина важнее оказывалась номенклатура, а не термин, обозначающий «лад». Например, система «двенадцати ладов» будет еще продолжать бытовать на западе исламского мира в виде двенадцати звукорядов-ангам, а на востоке - в виде двенадцати парде: в трактате Мухаммада Нишапури (Иран, XIII в.) и в литературном сочинении Тути-наме («Книга попугая») Зийа ад-Дина Нахшаби (Северо-Западная Индия, XIV в.). Известно, что первый опыт применения термина макам принадлежит персидскому философу Кутб ад-Дину ашШирази в энциклопедическом труде «Жемчужина короны для украшения Даббаджа» (Дуррат ат-тадж фи каррат ад-Даббадж, ок. 1309) - в сочинении, написанном для правителя Гилана, области на территории югозападного побережья Каспийского моря, где впервые появились известные наименования ладов-парде. Подобно Сафи ад-Дину, АшШирази рассматривал те же самые октавные звукоряды, но с разделением каждого еще на два «отдела» (шуббат - мн.ч. от араб. шубба «отдел», «ячейка») - на верхнюю и нижнюю части октавы. Он развил положения Сафи адДина в отношении структурной значимости ладовых комплексов не только октавного диапазона, но и кварто-квинтового, поскольку шу'бат - это самостоятельные музыкальные синтагмы. Кроме того, Кутб ад-Дин уделил внимание различным функциям отдельных тонов и ввел еще термин таркиб («комбинация»), который обозначал способ соединения мелодико-синтаксических образований. В результате, в начале XIV века теоретическая мысль в описании ладов оказалась приближенной еще более к персидской исполнительской практике, выражая то, что было важным для создания конкретных музыкальных форм, основанных на развитии лада.

Сугубо теоретические аспекты ладообразования, помогающие различать основные музыкальные категории в трактатах Сафи ад-Дина и Кутб ад-Дина, обстоятельно рассмотрены О. Райтом [25]. По мнению английского ученого, рукопись Аш-Ширази - это наиболее ранний источник, где термин макам был употреблен в отношении музыки. Однако, упоминается он персидским автором редко, «иногда и без очевидного отнесения к какой-либо специальной категории» музыки, а окончательная «замена арабского термина шадд на макам произошла уже в последующих трактатах, поскольку Аш-Ширази в основном использовал термин парда, как эквивалентный термину шадд» [25, с. 143]. Теоретические положения Сафи ад-Дина и Кутб ад-Дина приобрели широкую известность не только в центре, но и на востоке исламского мира, в меньшей степени - у западных арабов (в Магрибе). Приемниками его учения стали: 'Абд ал-Кадир ал-Мараги (ум. 1435), 'Абд арРахман Джами (ум. 1492), 'Абд ал-Хамид алЛадики (конец XV - начало XVI вв.), Наджм ад-Дин Каукаби Бухара'и (ум.1576) и другие.

Для получения более полной картины употребления категорий макам, аваз, шу'бе и других необходимо тщательное изучение рукописей XV-XVII веков. Однако, на основании имеющихся данных уже сейчас можно отметить, что замена употребляемого Сафи адДином термина шадд термином макам происходила при переводе его трактата турецкими авторами. Так, в первом переводе на турецкий язык «Книги кругов», выполненным Ахмедом оглу Шюкруллахом в начале XV века, термин макам появляется вместо употребляемого в оригинале термина шадд, но только в последнем разделе трактата - там, где Ал-Урмави говорит о воздействии двенадцати ладов на состояния человека [34, с. 90]. Замена терминов и принципов систематизации Сафи ад-Дина происходит при переводе его трактата другим турецким автором Сейди на рубеже XV-XVI веков [35]. В данной турецкой рукописи двенадцать основных звукорядов Сафи ад-Дина 
обозначены с самого начала термином макамат, а не шудуд; и вместо шести авазат, названо семь авазе и всего четыре шу'бе - вместо двадцати четырех, как это было у Кутб адДина. Однако, термин макам употреблялся не во всех трактатах в качестве прямого аналога музыкально-«техническим» терминам шудуд, парде, ангам, адвар. Например, в трактатах Ал-Мараги и Джами термин макам отделялся от других терминов, наполняясь значением «ученого музыкального искусства», связанного с высшей душой (рyx) человека. Об этих изменениях в терминологии и разногласиях в определении номенклатурных качеств ладовой системы нередко говорили сами средневековые авторы (Ал-Ладики). В то же время все это не меняло представления о макаме, как о центральном понятии из области ладообразования, относимом, прежде всего, к интервальной структуре лада.

По всей вероятности, введение термина макам осуществлялось широко в музыкальных трактатах (на персидском и турецком языках) на протяжении XV века. В связи с этим ценным является сделанное 'Абд ал-Кадир ал-Мараги в начале XV века замечание: «то, что арабы называют шудуд, известно как парде или макам в Персии» [25, с.169]. Оно подтверждает смысловую тождественность одновременно бытующих трех основных категорий, употребляемых для обозначения интервальной структуры лада - звукоряда. Здесь обращает на себя внимание еще одна мысль прославленного персидского музыканта. Ведь Ал-Мараги приписывает употребление термина макам иранцам, а не арабам. Не удивительно, что к такому же заключению приходит Э. Нойбауэр. Основываясь на изучении арабских документов по музыке, он утверждает: «В арабских источниках сам термин макам впервые появился в XVIII веке и не употреблялся вообще вплоть до XIX века. Лады по-прежнему назывались традиционно ангам (мн.ч. от араб. - нагма, «тон»). Термин макам, хотя и был арабским, впервые возник в Иране примерно в 1300 году и соответственно употреблялся в Османской Турции, откуда он и проник в восточно-арабские страны, и в очень позднее время. Легенды о происхождении и очень раннем использовании термина макам в арабских странах, которые можно найти в сопутствующей литературе, не имеют исторического обоснования» [36, с. 324]. Этот вывод авторитетнейшего историка подтверждается проведенным нами анализом теоре- тических данных о формировании ладовой системы в музыкальной культуре исламской цивилизации до XV века.

В результате стало ясно, что музыканты начали употреблять термин макам после XIV века в процессе рефлексии ладовых структур, существовавших в музыкальной практике 'аджамских («не говоривших на арабском языке») народов, т.е. иранцев. Этапным в развитии теории ладов стало учение Сафи ад-Дина алУрмави, создавшего в середине XIII века новую их систематизацию. Труды Сафи ад-Дина и Кутб ад-Дина аш-Ширази выявили со всей очевидностью иранскую культурную доминанту в развитии музыки исламской цивилизации. Следовательно, музыкальную категорию макам/макамат нельзя рассматривать аналогом общей категории «лад»/ «народные лады», поскольку она вводилась поздно, выражая новое цивилизационное восприятие музыки. Об этом свидетельствует способ введение термина макам в трактаты, где он окружался целой группой иных музыкальных терминов. Очевидно, что его употребление было вызвано не столько необходимостью рефлексии только параметров лада - арабские и персидские эквиваленты термину макам (шадд, парде, даур, ангам) продолжали существовать, заменяя друг друга у разных авторов, - сколько необходимостью обосновать новую исламскую концепцию музыки. Этому способствовала выделенная Сафи ад-Дином номенклатура «двенадцати» ладов, которая помогала выявить анропопатические свойства музыки, основанные на выразительности устоявшихся на практике ладо-мелодических комплексов.

Место музыкального искусства в культуре ислама после X века менялось. А поскольку термин макам широко бытовал в обществе, наполняясь теософским смыслом, то представления о макаме усваивались музыкантами в контексте культуры исламской цивилизации и выходили за узкие рамки музыкальной теории. Распространение представлений о «двенадцати макамат» позволяло лучше осознать связь музыки с накопленным в XIXIV веках духовным опытом мусульман, который отличался интенсивным усвоением мистического знания и созданием эзотерических практик, включавших в свои ритуалы музыку. Становление суфийских братств-тараик и разработка учения о душевных «станциях»макамат, теологическая реформа Абу Хамида Мухаммада ал-Газали (ум. 1111), расцвет пения лирической газели на персидском языке, 
имели огромное значение для формирования новой музыкальной эстетики и нового музыкально-поэтического репертуара. С введением понятия макам представление о музыке как о «веселье» (араб. тараб) дополнялось представлением о ней, как о «пище духовной» (перс. гиза'u-pyx). Этому способствовала новая систематизация ладовых структур, осуществляемая в музыкальной культуре исламской цивилизации после XIII века.

\section{Библиография:}

1. Джани-Заде Т.М. Перелистывая страницы архива М.Г. Харлапа // Альманах. - Вып.4 - Сб. научн. трудов ВМОМК им. М.И. Глинки. - Москва: Композитор, 2013. - С.490-502

2. Джани-заде Т.М. Мугам - импровизация на лад // Современные методы исследования в музыковедении. Вып. 31 - Сб. трудов. Гос. музыкально-педагогический институт им. Гнесиных - Москва, 1977. - С.56-82

3. Джани-Заде Т.М. Тематизм мугамной импровизации // Теоретические проблемы внеевропейских музыкальных культур. - Вып. 67 - Сб. трудов. Гос. музыкально-педагогический институт им. Гнесиных - Москва, 1983. - С.36-84

4. Джани-заде Т.М. Канон и импровизация // Макомы, мугамы и современное композиторское творчество Ташкент: издательство литературы и искусства им. Гафура Гуляма, 1978. - С.87-93

5. Джани-заде Т.М. Личность и канон в азербайджанских мугамах/ Сост. и ред. В.С. Виноградова // Музыка народов Азии и Африки - Вып. 5 - Москва: Советский композитор, 1987. - С.101-132

6. Elsner Jürgen. Der Begriff des maqām in Ägypten in neuerer Zeit // Beiträge zur musikwissenschaftlichen Forschung in der DDR - Bd.5. - Leipzig: VEB Deutscher Verlag für Musik, 1973. - 126 s.

7. Джани-заде Т. Музыка Исламской цивилизации // Вестник Российского гуманитарного научного фонда. № 1(30). - Москва, 2003. - С.156-169

8. Джани-Заде Т. Исламская музыка // Энциклопедия Кругосвет - 2003 - Электронный pecypc - URL: http:// www.krugosvet.ru/articles/106/1010663/1010663a-1.htm

9. Джани-заде Т.М. Азербайджанские мугамы. Проблема музыкального мышления в искусстве «макамат» // Дисс. ...канд. иск. - Москва, 1983. - 224 с. (прилож. - 140 с.)

10. Джани-заде Т.М. Хал-макам как принцип искусства «макамат» // Суфизм в контексте мусульманской культуры. - Москва: ГРВЛ Наука, 1989. - С. 319-338

11. Кароматов Ф., Эльснер Ю. Макам и маком / Сост. и ред. В.С. Виноградова // Музыка народов Азии и Африки. - Вып.4. - Москва: Советский композитор, 1984. - С. 88-134

12. Maqām - Rāga - Zeilenmelodik, Konzeptionen und Prinzipien der Musikproduktion / Hrg. von J. Elsner // Materialien der 1. Arbeitstagung der Study Group "maqām” beim International Council for Traditional Music vom 28. Juni bis 2. Juli 1988 in Berlin. - Berlin, 1989. - 344 p.

13. Regionale maqām-Traditionen in Geschichte und Gegenwart / Hrg. von J. Elsner gemeinsam mit G. Jähnichen // Materialien der 2. Arbeitstagung der Study Group "maqām” des International Council for Traditional Music vom 23. bis 28. März 1992 in Gosen bei Berlin. - Berlin, 1992. - 593 p.

14. The Structure and Idea of Maqām, Historical Approaches / Ed. by J. Elsner and R.P. Pennanen // Proceedings of the Third Meeting of the ICTM Maqām Study Group Tampere-Virrat, 2-5 October 1995. - Tampere: University of Tampere, 1997. - 202 p. (Department of Folk Tradition Publication - Vol. 24)

15. Maqām Traditions of Turkic Peoples / Ed. by J. Elsner and G. Jähnichen // Proceedings of the Fourth Meeting of the ICTM Study Group “maqām” Istanbul, 18-24 October 1998. - Berlin: trafo verlag Dr. Wolfgang Weist, 2006. $-278 \mathrm{p}$.

16. Intercultural Comparison of Maqām and Related Phenomena / Ed. by J. Elsner and G. Jähnichen // Proceedings of the Fifth Meeting of the ICTM Study Group “maqām” Samarkand, 26-30 August 2001. - Berlin: trafo Verlagsgruppe Dr. Wolfgang Weist, 2008. - 222 p.

17. Muqam in and outside of XinjiangChina / Ed. by J. Elsner and G. Jähnichen// Proceedings of the 6th Meeting of the ICTM Study Group “maqām”, Urumqi 2006. - Urumqi: Xinjiang Art Photography Publishing House, 2009. $-453 \mathrm{p}$.

18. The mugam of Azerbaijan and related traditions in Middle East / Ed. by F. Ali-Sade and S. Agaeva // Proceedings of the 7th Symposium of the ICTM Study Group "maqām" within the framework of the International Festival “Space of Mugam”, Baku 15-17 March 2011. - Baku: Şərq-Qərb, 2013. - 191 p.

19. Джани-заде Т. Макам как объект музыковедения // Международная ассоциация по изучению культур Центральной Азии. - Информационный бюллетень. - Вып. 14. - Москва: Наука, 1988. - С.76-82 
20. Джани-заде Т.М. Поэтика музыки в исламе: к постижению ритуала и музыки в суфизме // Невербальное поле культуры. Тело, вещь, ритуал. - Москва: Российский гос. гуманитарный университет, 1996. - С.102-109

21. Джани-Заде Т.М. Этнический фактор в культуре Исламской цивилизации: к вопросу о тюркской музыкальной субкультуре в исламе // Музыкальная культура в исламо-христианском контексте. - Материалы Всероссийской научно-практической конференции. - Казань: Казанская гос. консерватория, 2009. - С.44-54

22. Джани-заде Т.М. Из музыкальной ориенталистики: Генри Джордж Фармер и его переписка с В.М. Беляевым // Альманах N 2. - Труды Гос. центрального музея музыкальной культуры им. М.И. Глинки. -Москва: Дека-ВC, 2003. - С.23-72.

23. Neubauer E. Die Theorie vom $\overline{1} q \bar{a} ‘ / /$ Arabische Musiktheorie von den Anfängen bis zum 6./12. Jahrhundert. Frankfurt am Main: Institut für Geschichte der Arabisch-Islamischen Wissenschaften, 1998. - S. 185-308 (The Science of Music in Islam. Vol.3)

24. Neubauer E. Die acht "Wege" der arabischen Musiklehre und der Oktoechos // Arabische Musiktheorie von den Anfängen bis zum 6./12. Jahrhundert. - Frankfurt am Main: Institut für Geschichte der Arabisch-Islamischen Wissenschaften, 1998. - S.1-42 (The Science of Music in Islam. Vol.3)

25. Wright O. The Modal System of Arab and Persian Music A.D. 1250 - 1300. - London: Oxford University Press, 1978. - 302 p. (London Oriental Series. Vol. 28)

26. Раджабов А. Традиции музыкальной культуры эпохи Сасанидов. - Душанбе, 2004. - 108 с.

27. Рейснер М.Л., Чалисова Н.Ю. Персидская классическая лирика: к проблеме генезиса // Труды по культурной антропологии. - Памяти Г.А. Ткаченко. - Москва: ГРВЛ Наука, 2002. - С. 275-322

28. Джани-Заде Т.М. Типология «лютен» в культуре исламской цивилизации (VII-XVII века) // Вопросы этномузыкознания - № 1 (10) - Москва: Российская академия музыки им. Гнесиных, 2015 - C.66-113

29. Djani-zade Tamila. The concept of radif in Iranian and Azerbaijanian dastgāh/ Ed. by J. Elsner and G. Jähnichen // Proceedings of the Fifth Meeting of the ICTM Study Group "maqām” Samarkand, 26-30 August 2001. - Berlin: trafo Verlagsgruppe Dr. Wolfgang Weist, 2008. - P.41-66

30. Neubauer E. Arabische Anleitungen zur Musiktherapie // Zeitschrift für Geschichte der Arabisch-Islamischen Wissenschaften. - Bd.6. - Frankfurt am Main: Institut für Geschichte der Arabisch-Islamischen Wissenschaften an der Johann Wolfgang Goethe-Universität, 1990. - S. 227-272

31. Kābous nāmah par L'emir Unsur-U1-Ma'āli Keykāvous, Ibn Eskandar, Ibn Qabous, IbnVushmgir, Ibn Ziār, Prince de la dynastie des Ziārides / Ed. par Said Naficy. - Teheran, 1312 H. - 1933. - P.131-134.

32. Низами Гянджеви. Хосров и Ширин // Филологический перевод с фарси и комментарии Г.Ю. Алиева, М.Н. Османова. - Баку: Элм, 1985. - 440 с.

33. Farmer, Henry George. The influence of Music from Arabic Sources / Ed. by Eckhard Neubauer // Studies in Oriental Music. - First Volume: History and Theory. - Frankfurt am Main: Institute for History of Arabic-Islamic Science at the Johann Wolfgang Goethe University, 1997. -P.291-326. (Reprint of writings published in the years 1925-1966)

34. Şükrullah Ahmed Oğlu. Şükrullah'in Risālesi ve 15.Yüzyıl Şark Musikisi Nazariyatı / Açılamalı, Tenkidli ve Tıpkıbasım Murat Bardakçı. - Istanbul: Pan Yaymeılık, 2011. - 273 p.

35. Seydī's Book on Music. A 15-th Century Turkish Discourse/ Translated, Annotated and Edited by E. PopescuJudetz in Collaboration with E. Neubauer // Ed. by Fuat Sezgin. - Frankfurt am Main: Institute for the History of Arabic-Islamic Science at the Johann Wolfgang Goethe University, 2004. - 276 p. (The Science of Music in Islam. Vol. 6)

36. Neubauer E. Glimpses of Arab Music in Ottoman Times from Syrian and Egyptian Sources // Zeitschrift für Geschichte der Arabisch-Islamischen Wissenschaften. - Bd. 13. - Frankfurt am Main: Institut für Geschichte der Arabisch-Islamischen Wissenschaften, 2000. - S.317-365

\section{References (transliterated):}

1. Dzhani-Zade T.M. Perelistyvaya stranitsy arkhiva M.G. Kharlapa // Al'manakh. - Vyp.4 - Sb. nauchn. trudov VMOMK im. M.I. Glinki. - Moskva: Kompozitor, 2013. - S.490-502

2. Dzhani-zade T.M. Mugam - improvizatsiya na lad // Sovremennye metody issledovaniya v muzykovedenii. Vyp. 31 - Sb. trudov. Gos. muzykal'no-pedagogicheskii institut im. Gnesinykh - Moskva, 1977. - S.56-82

3. Dzhani-Zade T.M. Tematizm mugamnoi improvizatsii // Teoreticheskie problemy vneevropeiskikh muzykal'nykh kul'tur. - Vyp. 67 - Sb. trudov. Gos. muzykal'no-pedagogicheskii institut im. Gnesinykh - Moskva, 1983. S.36-84 
4. Dzhani-zade T.M. Kanon i improvizatsiya // Makomy, mugamy i sovremennoe kompozitorskoe tvorchestvo Tashkent: izdatel'stvo literatury i iskusstva im. Gafura Gulyama, 1978. - S.87-93

5. Dzhani-zade T.M. Lichnost' i kanon v azerbaidzhanskikh mugamakh/ Sost. i red. V.S. Vinogradova // Muzyka narodov Azii i Afriki - Vyp. 5 - Moskva: Sovetskii kompozitor, 1987. - S.101-132

6. Elsner Jürgen. Der Begriff des maqām in Ägypten in neuerer Zeit // Beiträge zur musikwissenschaftlichen Forschung in der DDR - Bd.5. - Leipzig: VEB Deutscher Verlag für Musik, 1973. - 126 s.

7. Dzhani-zade T. Muzyka Islamskoi tsivilizatsii // Vestnik Rossiiskogo gumanitarnogo nauchnogo fonda. № 1(30). - Moskva, 2003. - S.156-169

8. Dzhani-Zade T. Islamskaya muzyka // Entsiklopediya Krugosvet - 2003 - Elektronnyi resurs - URL: http:// www.krugosvet.ru/articles/106/1010663/1010663a-1.htm

9. Dzhani-zade T.M. Azerbaidzhanskie mugamy. Problema muzykal'nogo myshleniya v iskusstve "makamat" // Diss. ...kand. isk. - Moskva, 1983. - 224 s. (prilozh. - 140 s.)

10. Dzhani-zade T.M. Khal-makam kak printsip iskusstva "makamat" // Sufizm v kontekste musul'manskoi kul'tury. - Moskva: GRVL Nauka, 1989. - S. 319-338

11. Karomatov F., El'sner Yu. Makam i makom / Sost. i red. V.S. Vinogradova // Muzyka narodov Azii i Afriki. Vyp.4. - Moskva: Sovetskii kompozitor, 1984. - S. 88-134

12. Maqām - Rāga - Zeilenmelodik, Konzeptionen und Prinzipien der Musikproduktion / Hrg. von J. Elsner // Materialien der 1. Arbeitstagung der Study Group "maqām" beim International Council for Traditional Music vom 28. Juni bis 2. Juli 1988 in Berlin. - Berlin, 1989. - 344 p.

13. Regionale maqām-Traditionen in Geschichte und Gegenwart / Hrg. von J. Elsner gemeinsam mit G. Jähnichen // Materialien der 2. Arbeitstagung der Study Group "maqām" des International Council for Traditional Music vom 23. bis 28. März 1992 in Gosen bei Berlin. - Berlin, 1992. - 593 p.

14. The Structure and Idea of Maqām, Historical Approaches / Ed. by J. Elsner and R.P. Pennanen // Proceedings of the Third Meeting of the ICTM Maqām Study Group Tampere-Virrat, 2-5 October 1995. - Tampere: University of Tampere, 1997. - 202 p. (Department of Folk Tradition Publication - Vol. 24)

15. Maqām Traditions of Turkic Peoples / Ed. by J. Elsner and G. Jähnichen // Proceedings of the Fourth Meeting of the ICTM Study Group "maqām” Istanbul, 18-24 October 1998. - Berlin: trafo verlag Dr. Wolfgang Weist, 2006. $-278 \mathrm{p}$.

16. Intercultural Comparison of Maqām and Related Phenomena / Ed. by J. Elsner and G. Jähnichen // Proceedings of the Fifth Meeting of the ICTM Study Group "maqām" Samarkand, 26-30 August 2001. - Berlin: trafo Verlagsgruppe Dr. Wolfgang Weist, 2008. - 222 p.

17. Muqam in and outside of XinjiangChina / Ed. by J. Elsner and G. Jähnichen// Proceedings of the 6th Meeting of the ICTM Study Group "maqām”, Urumqi 2006. - Urumqi: Xinjiang Art Photography Publishing House, 2009. $-453 \mathrm{p}$.

18. The mugam of Azerbaijan and related traditions in Middle East / Ed. by F. Ali-Sade and S. Agaeva // Proceedings of the 7th Symposium of the ICTM Study Group "maqām" within the framework of the International Festival "Space of Mugam", Baku 15-17 March 2011. - Baku: Şərq-Qərb, 2013. - 191 p.

19. Dzhani-zade T. Makam kak ob"ekt muzykovedeniya // Mezhdunarodnaya assotsiatsiya po izucheniyu kul'tur Tsentral'noi Azii. - Informatsionnyi byulleten'. - Vyp. 14. - Moskva: Nauka,1988. - S.76-82

20. Dzhani-zade T.M. Poetika muzyki v islame: k postizheniyu rituala i muzyki v sufizme // Neverbal'noe pole kul'tury. Telo, veshch', ritual. - Moskva: Rossiiskii gos. gumanitarnyi universitet, 1996. - S.102-109

21. Dzhani-Zade T.M. Etnicheskii faktor v kul'ture Islamskoi tsivilizatsii: $\mathrm{k}$ voprosu o tyurkskoi muzykal'noi subkul'ture $\mathrm{v}$ islame // Muzykal'naya kul'tura v islamo-khristianskom kontekste. - Materialy Vserossiiskoi nauchno-prakticheskoi konferentsii. - Kazan': Kazanskaya gos. konservatoriya, 2009. - S.44-54

22. 22. Dzhani-zade T.M. Iz muzykal'noi orientalistiki: Genri Dzhordzh Farmer i ego perepiska s V.M. Belyaevym // Al'manakh N 2. - Trudy Gos. tsentral'nogo muzeya muzykal'noi kul'tury im. M.I. Glinki. -Moskva: Deka-VS, 2003. - S.23-72.

23. Neubauer E. Die Theorie vom $\overline{1} q \bar{a} \bar{a}^{-} / /$Arabische Musiktheorie von den Anfängen bis zum 6./12. Jahrhundert. Frankfurt am Main: Institut für Geschichte der Arabisch-Islamischen Wissenschaften, 1998. - S. 185-308 (The Science of Music in Islam. Vol.3)

24. Neubauer E. Die acht "Wege" der arabischen Musiklehre und der Oktoechos // Arabische Musiktheorie von den Anfängen bis zum 6./12. Jahrhundert. - Frankfurt am Main: Institut für Geschichte der Arabisch-Islamischen Wissenschaften, 1998. - S.1-42 (The Science of Music in Islam. Vol.3)

25. Wright O. The Modal System of Arab and Persian Music A.D. 1250 - 1300. - London: Oxford University Press, 1978. - 302 p. (London Oriental Series. Vol. 28) 
26. Radzhabov A. Traditsii muzykal'noi kul'tury epokhi Sasanidov. - Dushanbe, 2004. - 108 s.

27. Reisner M.L., Chalisova N.Yu. Persidskaya klassicheskaya lirika: k probleme genezisa // Trudy po kul'turnoi antropologii. - Pamyati G.A. Tkachenko. - Moskva: GRVL Nauka, 2002. - S. 275-322

28. Dzhani-Zade T.M. Tipologiya «lyuten» v kul'ture islamskoi tsivilizatsii (VII-XVII veka) // Voprosy etnomuzykoznaniya - № 1 (10) - Moskva: Rossiiskaya akademiya muzyki im. Gnesinykh, 2015 - S.66-113

29. Djani-zade Tamila. The concept of radif in Iranian and Azerbaijanian dastgāh/ Ed. by J. Elsner and G. Jähnichen // Proceedings of the Fifth Meeting of the ICTM Study Group "maqām” Samarkand, 26-30 August 2001. - Berlin: trafo Verlagsgruppe Dr. Wolfgang Weist, 2008. - P.41-66

30. Neubauer E. Arabische Anleitungen zur Musiktherapie // Zeitschrift für Geschichte der Arabisch-Islamischen Wissenschaften. - Bd.6. - Frankfurt am Main: Institut für Geschichte der Arabisch-Islamischen Wissenschaften an der Johann Wolfgang Goethe-Universität, 1990. - S. 227-272

31. Kābous nāmah par L'emir Unsur-Ul-Ma'āli Keykāvous, Ibn Eskandar, Ibn Qabous, IbnVushmgir, Ibn Ziār, Prince de la dynastie des Ziārides / Ed. par Said Naficy. - Teheran, 1312 H. - 1933. - P.131-134.

32. Nizami Gyandzhevi. Khosrov i Shirin // Filologicheskii perevod s farsi i kommentarii G. Yu. Alieva, M.N. Osmanova. - Baku: Elm, 1985. - 440 s.

33. Farmer, Henry George. The influence of Music from Arabic Sources / Ed. by Eckhard Neubauer // Studies in Oriental Music. - First Volume: History and Theory. - Frankfurt am Main: Institute for History of Arabic-Islamic Science at the Johann Wolfgang Goethe University, 1997. -P.291-326. (Reprint of writings published in the years 1925-1966)

34. Şükrullah Ahmed Oğlu. Şükrullah’in Risālesi ve 15.Yüzyıl Şark Musikisi Nazariyatı / Açılamalı, Tenkidli ve Tıpkıbasım Murat Bardakçı. - Istanbul: Pan Yaymeılık, 2011. - 273 p.

35. Seydī's Book on Music. A 15-th Century Turkish Discourse/ Translated, Annotated and Edited by E. PopescuJudetz in Collaboration with E. Neubauer // Ed. by Fuat Sezgin. - Frankfurt am Main: Institute for the History of Arabic-Islamic Science at the Johann Wolfgang Goethe University, 2004. - 276 p. (The Science of Music in Islam. Vol. 6)

36. Neubauer E. Glimpses of Arab Music in Ottoman Times from Syrian and Egyptian Sources // Zeitschrift für Geschichte der Arabisch-Islamischen Wissenschaften. - Bd. 13. - Frankfurt am Main: Institut für Geschichte der Arabisch-Islamischen Wissenschaften, 2000. - S.317-365 